\title{
STUDENT WITH HEALTH-RELATED PROBLEMS AND PHYSICAL ACTIVITY PARTICIPATION
}

\author{
Melvin J. Hernandez \\ Graduate School, Laguna State Polytechnic University, Santa Cruz, Laguna, Philippines
}

Article DOI: https://doi.org/10.36713/epra7480

DOI No: 10.36713/epra7480

\begin{abstract}
This study determined the students with health-related problems and physical activity participation. Specifically, the study sought answers to the following questions: What is the status of the common health-related problems of the students; What is the level of physical activity participation; What is the level of performance in physical education in terms of grades; Is there a significant relationship between health-related problems and performance in physical education; and Is there a significant relationship between physical activity participation and performance in physical education?
\end{abstract}

This study utilized a correlation research design to determine students with health-related problems and physical activity participation. The main source of data of the study is the survey questionnaire which was prepared by the researcher and statistical use of simple descriptive statistics such as the frequency counts and percentages to determine the mean level of the status common health-related problems of the students taking Physical Education subject in Cavite State University Main Campus.

In order to conduct this study, letters were sent to the University President of the Cavite State University, Hernando D. Robles EdD. and the Vice President for Academic Affairs, to ask for permission and approval to conduct the study.

The self-made questionnaire was checked by the thesis adviser. Face validation of the contents of the questionnaire was done by the adviser of the researcher and other persons with specialization in the field.

Researchers used purposive sampling in choosing a specific subset of people to be included as the respondents of the study. Each individual was chosen entirely by chance and each member of the population had an equal chance of being included in the sample. Respondents are the students with health-related problems taking-up Physical Education subject with one hundred one (101) respondents.

The purpose of the study is to offer literature and findings that may be useful in conducting future studies more particularly to the students with health-related problems and physical activity participation.

The methods used was used statistically analyze and interpret the data gathered through the frequency counts and percentage, weighted mean and the Pearson correlation coefficient which is the statistical test in which the test statistic has an R-value under the null hypothesis. It is appropriate method when correlating statistical models that have been to use to a data set, in order to identify the model that best fits the population from which the data were sampled.

The implication of this research is to find out the importance of assessing the students with health-related problems and their physical activity participation in every Physical Education subject.

The result showed that there is a significant relationship between health-related problems and performance in physical education. Also, there is a significant relationship between physical activity participation and performance. This will lead to a conclusion that the hypotheses were accepted.

KEYWORDS: Physical Activity Participation, Health-related Problems, Performance task 


\section{SJIF Impact Factor 2021: 8.013| ISI I.F.Value:1.241| Journal DOI: 10.36713/epra2016 ISSN: 2455-7838(Online) EPRA International Journal of Research and Development (IJRD)

\section{INTRODUCTION}

Students get a lot of benefits from attending and participating in physical education classes. Physical education classes can help students to become more aware of the value of a healthy lifestyle. The students can also maintain a higher level of knowledge as a result of the overall fitness. This information can help them to make wise decisions concerning their safety, health, and wellbeing.

Physical Education is "education through the physical". It aims to develop students' physical competence and knowledge of movement and safety, and their ability to use these to perform in a wide range of activities associated with the development of an active and healthy lifestyle. It also develops students' confidence and generic skills, especially those of collaboration, communication, creativity, critical thinking and aesthetic appreciation. These, together with the nurturing of positive values and attitudes in $\mathrm{PE}$, provide a good foundation for students' lifelong and life-wide learning.

In assessing the skills and knowledge of the student in each topic in physical education, teachers give them a certain task to demonstrate their knowledge, understanding and proficiency to a given topic. Performance tasks are the tool that physical educators use to measure the skills and fitness levels of students are learning and attaining in their PE class. Assessing in PE helps to show others (parents, school administrators and other teachers) what students are learning in their physical education class. Performance task serves as the evidence of learning of the students. They should demonstrate what students know or what they can do.

Performance tasks are needed to let students, parents and teachers know what areas or skills need to be improved upon. It can also be used to help show others the importance of PE classes. It is important to use a different task to measure and validate student learning that is happening in the PE program. As PE teachers, using performance task help display that we are doing our jobs as a physical educator. When student performance task shows their fitness/skill levels are increasing, that helps to prove that your physical education program is credible and valuable.

In the past few years, most of the students do not know the importance of physical education and physical activities. Due to lack of physical activities during childhood, most of them are having healthrelated problems such as obesity, asthma, heart problems and others. Therefore, most students affect their performance and not even participate in any activities related to Physical Education. In this matter, most of the students with health-related problems made excuses of their condition not to perform such task in their physical education subject especially in college.

\section{OBJECTIVES}

The purpose of this study is to identify the relationship of the physical activity participation of the students with health-related problems in performance to Physical Education classes in Cavite State University Main Campus.

Specifically, this research study also aims to answer the following questions:

1. What is the status of the common health-related problems of the students?

2. What is the level of physical activity participation?

3. What is the level of performance in physical education in terms of grades?

4. Is there a significant relationship between healthrelated problems and performance in physical education?

5. Is there a significant relationship between physical activity participation and performance in physical education?

\section{METHODOLOGY}

The researcher will use the correlational research that establish a relationship between two closely-knit entities and how one impacts the other and what are the changes that are eventually observed. The study will determine if the student with health-related problems currently taking physical education classes in Cavite State University - Main Campus and the physical activity participation have significant relationship to the performance in Physical Education classes.

The sampling technique used in this study is purposive sampling. Purposive sampling (also known as judgment, selective or subjective sampling) is a sampling technique in which researcher relies on his or her own perspicacity when choosing the respondents to participate in the study (Black, K. 2010). The researcher will conduct a purposive sampling by choosing those students with the health-related problem taking physical education classes.

In order to conduct this study, letters were sent to the University President of the Cavite State University, Hernando D. Robles EdD. and the Vice President for Academic Affairs, to ask for permission and approval to conduct the study. 


\section{EPRA International Journal of Research and Development (IJRD)}

The self-made questionnaire was checked by the thesis adviser. Face validation of the contents of the questionnaire was done by the adviser of the researcher and other persons with specialization in the field.

The methods used was used statistically analyze and interpret the data gathered through the frequency counts and percentage, weighted mean and the Pearson correlation coefficient which is the statistical test in which the test statistic has an R-value under the null hypothesis. It is appropriate method when correlating statistical models that have been to use to a data set, in order to identify the model that best fits the population from which the data were sampled.

\section{RESULT AND DISCUSSION}

This chapter deals with the presentation, analysis and interpretation of data gathered to answer the sub problem relative to the main problem of this study on the student with health-related problems and physical activity participation. This part discusses the findings of the study based on the research questions.

Table 1. Status of the common health-related problems of the students

\begin{tabular}{|c|c|c|c|}
\hline \multicolumn{2}{|c|}{ Health-Related Problems of Student } & frequency & percentage \\
\hline \multirow{3}{*}{$\begin{array}{l}\text { Student with Chronic Health } \\
\text { Problem }\end{array}$} & Asthma & 28 & 27.72 \\
\hline & Lupus & 2 & 1.98 \\
\hline & Lymphatic & 1 & 0.99 \\
\hline \multirow{10}{*}{$\begin{array}{l}\text { Student with Injuries } \\
\text { and Joints) }\end{array}$} & Scoliosis & 11 & 10.89 \\
\hline & Thoracic Scoliosis & 3 & 2.97 \\
\hline & Dextroscoliosis & 3 & 2.97 \\
\hline & Bone Fracture & 2 & 1.98 \\
\hline & ACL & 1 & 0.99 \\
\hline & Muscle Strain / Sprain & 3 & 2.97 \\
\hline & Thoracic Leviscoliosis & 1 & 0.99 \\
\hline & Injuries (Knee, Shoulder, Ankle) & 3 & 2.97 \\
\hline & Twisted wrist & 2 & 1.98 \\
\hline & Bone Tuberculosis & 1 & 0.99 \\
\hline \multirow{7}{*}{$\begin{array}{lcc}\text { Student with } & \text { Heart } & \text { or } \\
\text { Cardiovascular Conditions } & \end{array}$} & Atrial Septal Defects & 2 & 1.98 \\
\hline & Hypotension & 3 & 2.97 \\
\hline & Coronary Artery Disease & 5 & 4.95 \\
\hline & Mitral Valve Prolapse & 1 & 0.99 \\
\hline & Sinus Tachycardia & 1 & 0.99 \\
\hline & Atrial Septal Defects & 2 & 1.98 \\
\hline & Ventricular Septal Defect & 1 & 0.99 \\
\hline \multirow[t]{2}{*}{ Malnutrition and Obesity } & Malnutrition & 3 & 2.97 \\
\hline & Obesity & 4 & 3.96 \\
\hline Early Pregnancy and Childbirth & Childbirth & 2 & 1.98 \\
\hline \multirow{12}{*}{$\begin{array}{l}\text { Other Health-related Condition } \\
\text { of the students }\end{array}$} & Eczema & 3 & 2.97 \\
\hline & UTI & 2 & 1.98 \\
\hline & Allergic Rhinitis & 3 & 2.97 \\
\hline & Anemia & 1 & 0.99 \\
\hline & Pneumonia & 1 & 0.99 \\
\hline & Serious Hyperventilation Syndrome & 1 & 0.99 \\
\hline & Hypertension & 1 & 0.99 \\
\hline & Nephrotic Syndrome & 1 & 0.99 \\
\hline & Back pain & 2 & 1.98 \\
\hline & Ovarian Cyst & 1 & 0.99 \\
\hline & Palpitation & 1 & 0.99 \\
\hline & Nose Bleeding & 1 & 0.99 \\
\hline
\end{tabular}




\section{EPRA International Journal of Research and Development (IJRD)}

\section{Health-Related Problems}

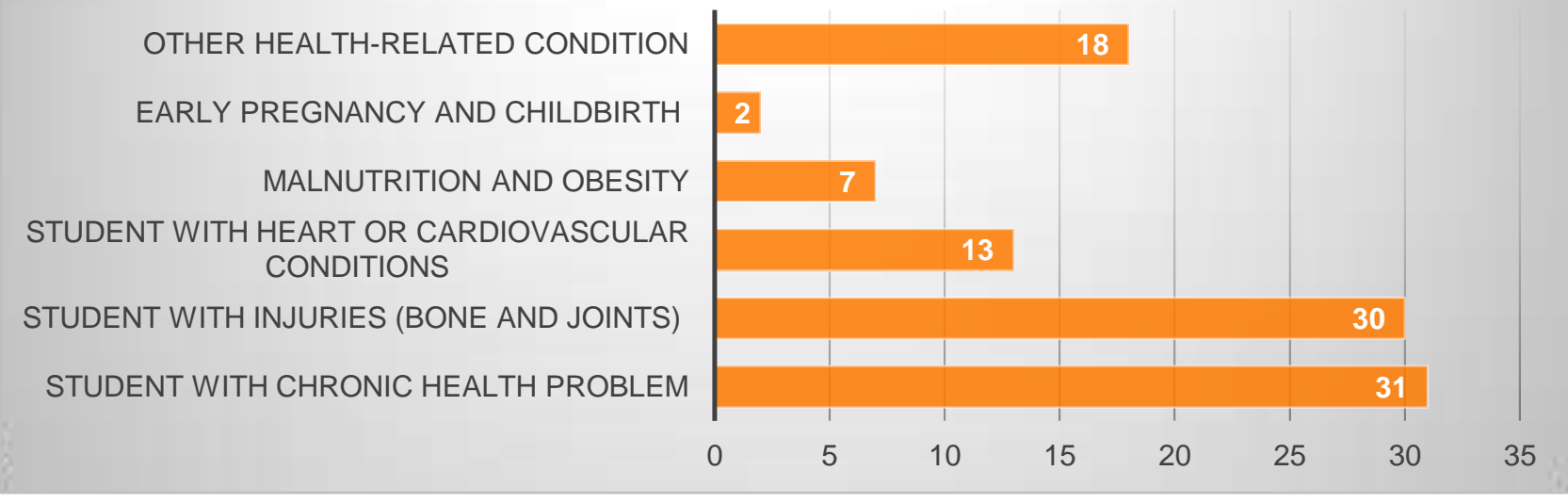

Figure 2. Status of the Common Health-Related Problems of the Students

Graph shows that the condition "Students with Chronic Health Problems with Asthma, Lupus and Lymphatic" have the highest frequency of thirty-one (31) or $30.69 \%$ of the total respondents. And have thirty (30) or $29.70 \%$ of the respondent are "Students with Injuries (Bone and Joints) with Scoliosis, Thoracic Scoliosis, Dextroscoliosis, Bone Fracture, ACL, Muscle Strain/Sprain, Thoracic Levi scoliosis, Injuries (knee, shoulder, ankle) and Twisted Wrist". While the condition "Early Pregnancy and Childbirth" received the lowest frequency of two (2) or $1.98 \%$ of the total respondents.

This means that the status of the common health-related problems of the students were majority have chronic health problems and with injuries in the bones and joints during the time of the study.

Table 2. Level of Physical Activity Participation of the Students

\begin{tabular}{|l|c|c|c|}
\hline Statements & Mean & SD & Remarks \\
\hline $\begin{array}{l}\text { I spend an hour or more when participating in physical activity } \\
\text { required in the subject. }\end{array}$ & 3.73 & 1.07 & Agree \\
\hline $\begin{array}{l}\text { I put extra effort when participating in physical activity required in the } \\
\text { subject. }\end{array}$ & 3.99 & 1.03 & Agree \\
\hline I always try to finish any physical activity required in the subject. & 4.15 & 0.98 & Agree \\
\hline $\begin{array}{l}\text { I have "jus to pass" mentality in terms of participating any physical } \\
\text { activity required in the subject. }\end{array}$ & 2.87 & 1.31 & $\begin{array}{c}\text { Moderately } \\
\text { Agree }\end{array}$ \\
\hline I always participate in the physical activity given by the teacher. & 3.95 & 1.13 & Agree \\
\hline $\begin{array}{l}\text { I try to convince my teacher for me to be exempted in any physical } \\
\text { activity. }\end{array}$ & 2.26 & 1.14 & Disagree \\
\hline $\begin{array}{l}\text { Overall Mean } \mathbf{= 3 . 4 9} \\
\text { Standard Deviation }=\mathbf{1 . 3 0 7} \\
\text { Verbal Interpretation }=\mathbf{H i g h}\end{array}$ & & & \\
\hline
\end{tabular}

Legend:

\section{Scale}

5

4

3

2

1
Range Remarks

4.20-5.00 Strongly Agree

3.40-4.19 Agree

2.60-3.39 Moderately Agree

1.80-2.59 Disagree

1.00-1.79 Strongly Disagree
Verbal Interpretation

Very High

High

Moderately High

Low

Very Low 


\section{EPRA International Journal of Research and Development (IJRD)}

Based on the students' perceptions, the level of physical activity participation was generally high. They always try to finish any physical activity required in the subject have $(M=4.15, S D=0.98)$ and put extra effort when participating in physical activity required in the subject with $(M=3.99, S D=1.03)$. They try to convince teacher to be exempted in any physical activity with $(M=2.26, S D=1.14)$; and this item got the lowest rating. All item indicators got a verbal interpretation of low to high, as disclosed by the overall mean of 3.49 and supported with standard deviation value of 1.307 .

Table 3. Level of performance in physical education of the students in terms of grades

\begin{tabular}{|l|c|c|c|}
\hline Grade & frequency & $\mathbf{\%}$ & Adjectival Rating \\
\hline $1.25-1.00$ & 44 & $\mathbf{4 3 . 5 6}$ & Excellent \\
\hline $1.50-1.75$ & 36 & $\mathbf{3 5 . 6 4}$ & Very Satisfactory \\
\hline $2.00-2.25$ & 16 & $\mathbf{1 5 . 8 4}$ & Satisfactory \\
\hline $2.50-2.75$ & 5 & $\mathbf{4 . 9 5}$ & Fairly Satisfactory \\
\hline 3.00 & 0 & $\mathbf{0 . 0 0}$ & Passed \\
\cline { 1 - 2 } Total & $\mathbf{1 0 1}$ & $\mathbf{1 0 0 . 0 0}$ & \multirow{2}{*}{ Very Satisfactory } \\
\cline { 1 - 2 } Weighted Mean & 1.52 & & \\
\cline { 1 - 2 } Lowest Grade & 2.50 & & \\
\cline { 1 - 2 } Highest Grade & 1.00 & & \\
\cline { 1 - 2 } Standard Deviation & 1.307 & & \\
\end{tabular}

Table 3 shows the level of performance in physical education of the students in terms of grades, out of 101 students, the grade " 1.25 to 1.00 " got the highest frequency of forty-four (44) or $43.56 \%$ of the sample population and with descriptive equivalent of Excellent. And the grade "1.50 to 1.75 " has a frequency of thirty-six (36) or $35.64 \%$ of the sample population and with descriptive equivalent of Very Satisfactory. While the grade "2.50 to 2.75 " received the lowest frequency of five (5) or $4.95 \%$ of the sample population and with descriptive equivalent of Fairly Satisfactory.

With the weighted mean of 1.52 and supported value of standard deviation of 1.307 and the (Lowest Grade $=2.50$, Highest Grade $=1.00$ ) the level of performance in physical education of the students in terms of grades has a descriptive equivalent of Very Satisfactory.

Table 4. Significant relationship between health-related problems and performance in physical education

\begin{tabular}{|c|c|c|c|c|}
\hline health-related problems & $\begin{array}{c}\text { performance in } \\
\text { physical } \\
\text { education }\end{array}$ & $r$ - value & $\begin{array}{c}\text { Verbal } \\
\text { interpretation }\end{array}$ & Analysis \\
\hline Student with Chronic Health Problem & \multirow{6}{*}{ Grade } & 0.8859 & $\begin{array}{l}\text { High } \\
\text { correlation }\end{array}$ & Significant \\
\hline Student with Injuries (Bone and Joints) & & 0.9286 & $\begin{array}{l}\text { Very high } \\
\text { correlation }\end{array}$ & Significant \\
\hline $\begin{array}{l}\text { Student with Heart or Cardiovascular } \\
\text { Conditions }\end{array}$ & & 0.9667 & $\begin{array}{l}\text { Very high } \\
\text { correlation }\end{array}$ & Significant \\
\hline Malnutrition and Obesity & & 0.8484 & $\begin{array}{c}\text { High } \\
\text { correlation }\end{array}$ & Significant \\
\hline Early Pregnancy and Childbirth & & 0.9415 & $\begin{array}{l}\text { Very high } \\
\text { correlation }\end{array}$ & Significant \\
\hline Other Health-related Condition & & 0.7964 & $\begin{array}{c}\text { High } \\
\text { correlation }\end{array}$ & Significant \\
\hline
\end{tabular}




\section{EPRA International Journal of Research and Development (IJRD)}

Legend

$\begin{array}{ll}\text { Scale } & \text { Interpretation } \\ \pm 0.00 & \text { no correlation, no relationship } \\ \pm 0.01- \pm 0.20 & \text { very low correlation, almost negligible relationship } \\ \pm 0.21- \pm 0.40 & \text { slight correlation, definite but small relationship } \\ \pm 0.41- \pm 0.70 & \text { moderate correlation, substantial relationship } \\ \pm 0.71- \pm 0.90 & \text { high correlation, marked relationship } \\ \pm 0.91- \pm 0.99 & \text { very high correlation, very dependable relationship } \\ \pm 1.00 & \text { perfect correlation, perfect relationship }\end{array}$

Table 4 presents the relationship between health-related problems and performance in physical education.

The Student with Chronic Health Problem, Student with Injuries (Bone and Joints), Student with Heart or Cardiovascular Conditions, Malnutrition and Obesity, Early Pregnancy and Childbirth and Other Health-related Condition for grade performance in physical education shows high to very high correlation or very dependable relationship and have an analysis of significant at 0.05 level of significance. This means that the Student with Chronic Health Problem, Student with Injuries (Bone and Joints), Student with Heart or Cardiovascular Conditions, Malnutrition and Obesity,
Early Pregnancy and Childbirth and Other Healthrelated Condition has a direct relationship to the grade performance in physical education.

Based on the data, it is shown that there is a significant relationship between health-related problems and performance in physical education at 0.05 level of significance. It shows that the null hypothesis stating that "There is no significant relationship between health-related problems and performance in physical education" is rejected, it can infer that there is "significant" relationship between them.

Table 5. Significant relationship between physical activity participation and performance in physical education

\begin{tabular}{|l|c|c|c|c|}
\hline & $\begin{array}{c}\text { performance in physical } \\
\text { education }\end{array}$ & r - value & Verbal interpretation & Analysis \\
\hline $\begin{array}{l}\text { physical activity } \\
\text { participation }\end{array}$ & Grade & 0.9144 & Very high correlation & Significant \\
\hline
\end{tabular}

Legend

$\begin{array}{ll}\text { Scale } & \text { Interpretation } \\ \pm 0.00 & \text { no correlation, no relationship } \\ \pm 0.01- \pm 0.20 & \text { very low correlation, almost negligible relationship } \\ \pm 0.21- \pm 0.40 & \text { slight correlation, definite but small relationship } \\ \pm 0.41- \pm 0.70 & \text { moderate correlation, substantial relationship } \\ \pm 0.71- \pm 0.90 & \text { high correlation, marked relationship } \\ \pm 0.91- \pm 0.99 & \text { very high correlation, very dependable relationship } \\ \pm 1.00 & \text { perfect correlation, perfect relationship }\end{array}$

Table 5 presents the relationship between physical activity participation and performance in physical education.

The physical activity participation for grade performance in physical education shows very high correlation or very dependable relationship and have an analysis of significant at 0.05 level of significance. This means that the physical activity participation has a direct relationship to the grade performance in physical education.
Based on the data, it is shown that there is a significant relationship between physical activity participation and performance in physical education at 0.05 level of significance. It shows that the null hypothesis stating that "There is no significant relationship between physical activity participation and performance in physical education" is rejected, it can infer that there is "significant" relationship between them. 


\section{CONCLUSION}

Drawn the results of the study, the following results are set forth;

1. The null hypothesis stating that there is no significant relationship between health-related problems and performance in physical education is rejected, it can infer that there is "significant" relationship between them.

2. The null hypothesis stating that there is no significant relationship between physical activity participation and performance in physical education is rejected, it can infer that there is "significant" relationship between them.

\section{RECOMMENDATION}

Based from the study, the following recommendations can be taken into consideration for future studies;

1. Since there is a relationship between health-related problems and performance in physical education, future researchers may propose an alternative activity to cater the students with healthrelated problems.

2. Since there is a relationship between physical activity participation and performance in physical education, future researchers may propose a guideline and rubrics for the performance of the students with health-related problems. 